УДК $004.05+001.895$

\title{
ИННОВАЦИОННЫЕ ПРОГРАММНЫЕ ПРОДУКТЫ: МЕТОДЫ, МОДЕЛИ И ХАРАКТЕРИСТИКИ ЭКСПЕРТНОЙ ОЦЕНКИ КАЧЕСТВА ИНТЕРФЕЙСА
}

\author{
Ларин Сергей Николаевич \\ кандидат технических наук, \\ ведущий научный сотрудник \\ Центральный экономико-математический \\ институт РАН, г. Москва
}

\begin{abstract}
Аннотация: Интерфейс пользователя является важнейшей составляющей современных инновационных программных продуктов и одной из качественных характеристик. В статье обоснована возможность применения инструментария методов и моделей экспертной оценки для определения характеристик качества разработки интерфейса пользователя инновационных программных продуктов. Предложен подход к экспертной оценке качества уровня интерактивности инновационных программных продуктов на основе анализа качественных характеристик интерфейса пользователя. Разработана система показателей и критериев для формирования экспертной интегральной оценки качества интерфейса пользователя инновационных программных продуктов. Результаты исследования представляют интерес для пользователей инновационных программных продуктов, применяющих их при решении различных задач управления производственно-хозяйственной деятельностью отечественных предприятий.
\end{abstract}

Ключевые слова: Инновационный программный продукт, интерфейс пользователя, экспертная оценка, характеристики качества, методы и модели.

\section{INNOVATIVE SOFTWARE PRODUCTS: METHODS, MODELS AND CHARACTERISTICS EXPERT ASSESSMENT OF INTERFACE QUALITY}

\section{Larin Sergey Nicolaevich}

Abstract: The user interface is the most important component of modern innovative software products and one of the quality characteristics. The article 
substantiates the possibility of using the tools of methods and models of expert evaluation to determine the quality characteristics of the user interface development of innovative software products. An approach to the expert assessment of the quality of the level of interactivity of innovative software products based on the analysis of the quality characteristics of the user interface is offered. A system of indicators and criteria for the formation of an expert integrated assessment of the quality of the user interface of innovative software products has been developed. The results of the study are of interest to users of innovative software products that use them for the solving various problems of managing the production and economic activities of domestic enterprises.

Key words: Innovative software, user interface, expert assessment, quality characteristics, methods and models.

\section{Introduction.}

Currently, it is almost impossible to imagine a solution to various problems of managing the production and economic activities of the absolute majority of domestic enterprises without the use of modern innovative software products (ISP). Moreover, practice shows that domestic enterprises use quite a lot of different ISP to solve various management tasks [5]. However, there is a wide range of ISP that meet the requirements of the latest generation of standards (international and Russian ones), as well as a number of other regulatory and methodological documents [2, 3, 13]. Therefore, the relevance of solving the problem of determining the level of quality of the development of both the ISP as a whole and its individual components by using the model and methods of expert assessments increases significantly. One of these components is the user interface (UI) [1]. This article will justify the approach to the expert assessment of the quality of the level of interactivity of the ISP through the qualitative characteristics of the software.

\section{Main part.}

To assess the quality of the development of the ISP, it seems appropriate to determine its main innovative properties and then select the corresponding quality characteristics. The use of innovative technologies for the development of the modern ISP software gives them certain innovative properties. The most important among them are: interactivity; the use of modeling and multimedia tools to represent the content of the subject area of knowledge; the communicative interactions of the users of the software assess the quality of the development of the ISP, it seems appropriate to determine its main innovative properties and then select the corresponding quality 
characteristics. The use of innovative technologies for the development of modern ISP software gives them certain innovative properties. The most important among them are: interactivity; the use of modeling and multimedia tools to represent the content of the subject area of knowledge; the communicative interactions of the users of the ISP; the performance of the user of the ISP. But it is quite difficult to assess the quality of the development of ISP by its innovative properties. Even the four innovative properties mentioned above cannot simply be reduced to the same denominator, since they have different functional purposes, it seems appropriate to determine its main innovative properties and then select the corresponding quality characteristics. The use of innovative technologies for the development of the modern ISP software gives them certain innovative properties; the performance of the ISP user. But it is quite difficult to assess the quality of the development of IPS by its innovative properties. Even the four innovative properties mentioned above cannot simply be reduced to the same denominator, since they have different functional purposes.

Let's try by means of the ISP and IP determination reveal characteristics for the evaluation of the quality level of its development.

ISP is usually understood as a package of information application programs. It includes: a logically structured content of the subject area of knowledge, which combines a certain set of tasks to be solved; information content and metadata for individual subject areas of knowledge and their sections, software, necessary for the use of ISP in the course of managing the production and economic activities of the enterprise [4, 6, 7]. The ISP is based on the structured content of the subject area of knowledge, its information content, modern information technologies and software tools.

An integral part of the ISP is the UI or navigation system, which is a set of rules and procedures governing the interaction of users with the ISP. The UI combines all the components of the ISP and the information content of the subject area of knowledge that affect the interaction of users with the ISP. These include:

- composition of tasks solved with ISP;

- information platform, serving as basis for the ISP functioning;

- elements of ISP management;

- navigation between ISP blocks and modules;

- design of the screen presentation of the application of the ISP knowledge;

- means and formats of the reflection of the application of the ISP knowledge; 
- technologic devices for the input \& output of the information;

- algorithms of the dialogue interaction between users and ISP;

- feedback modes;

- options of the decision making by users in a certain application of the knowledge;

- documentation of the order of interaction between users and ISP [8, 9].

Standard instruments for the UI development are represented by the library of most important components of the interface (menu, buttons, scroll bars etc.), which can be supplemented by new ones, as well as be upgraded in the process of interaction between users and ISP.

For the development of the UI, a formalized model of the dialog interaction of users with the UI is used. Its practical implementation is based on the following principles of abstraction and functional content.

The first principle involves the separation between: user actions and the system of dialog interaction with the ISP; special content issues and goals of dialog interaction of users with the ISP; methods of presenting information content and technological devices for input and output of information arrays.

The second principle assumes the functional content of the model by: presenting in a simple and visual form the structure of the information content of a specific subject area of knowledge; ensuring the availability of information content for users of a specific subject area of knowledge; selecting information platforms for the functioning of the ISP [10].

In modern conditions for the UI development are used such high level means as Interface Builders (IB) and User Interface Management Systems (UIMS) [11].

UI interface builders are classified by groups:

1) instruments for the support of the UI creation by means of the code writing (UIMS and Toolkits);

2) interactive instrumental facilities, allowing to build the UI from «blanks» (buttons, menu, scroll bars etc.) (Interface Builders);

3) creation of the UI by means of the interrelation ship of certain components, which have been developed earlier (Component Architectures).

Toolkits represent instrumental means for the support of the UI creation by means of the writing of the code, including the library of basic components (menu, buttons, scroll bars etc.). Interface Builders represent interactive instrumental means, allowing to build an IU from «blanks» (buttons, menu, scroll bars etc.) [12]. 
It is better to call UIDS not design systems (UIDS - User Interface Development Systems), which have been created as instruments for the IS development, but UI management systems - UIMS (User Interface Management System). Such systems are represented as ISU components of a certain set of software modules, which totality corresponds to UIDS. So, the basic UIDS concept is based is based on the idea of the clear distinction between the UI and software [16].

The main functional characteristics of UIDS/UIMS include: working with input devices; checking the validity of information input formats; processing user errors; implementing feedback; support for updating/changing application data; support for UI development tasks; syntactic support for users in working with UI [17].

The structure of basic components of UIMS/UIDS looks as follows:

- applied level;

- dialogue level;

- presentation level (interactive means of development; file of descriptions; windows' management);

- instrumental level;

- in-built instrumental level;

- basic interface level of windows' system at the dialogue screen;

- data flow coding level [12].

The methods of expert quality assessment play an important role in the design of UI [4]. The reliability of the assessment affects the quality of the individual interface. Ensuring the usability of the IU allows users to focus on the features of interaction with the UI.

The ISO 9241-11 standard defines the quality of UI through the usability characteristic (practicality or usability), as "the degree to which a product can be used by certain users in a certain context of use to achieve certain goals with due efficiency, productivity and satisfaction" [14]. The ISO 9126-1 standard defines usability as the ability of an UI to be meaningful, learned, and attractive to the user under certain operating conditions [15].

There are four main criteria for the quality of any UI, namely: the speed of learning, the number of errors, the speed of work and subjective satisfaction (it is implied that the compliance of the UI with the tasks solved within the ISP is its inherent property). 
The speed of learning largely depends on how much the UI ISP encourages users to acquire new knowledge. It is obvious that users will only work with UI ISP if they have confidence that this will help them gain new knowledge. This approach is very similar to the return on investment, since no investor will invest money without the confidence that it will bring him income. This approach fully applies to the actions of users, in particular to the speed of their acquisition of new knowledge using the capabilities of the UI ISP. Naturally, users will use the features of the UI ISP only if they know about it. Therefore, the speed of learning depends on how well users know the capabilities of the UI ISP.

One of the important criteria for the expert assessment of the quality of the UI is the number of errors that users make in the process of interacting with the UI. By "error" we will understand only such actions of users that do not coincide with the goals of their actions in the process of interaction with the ISP. The most common three types of user errors in the process of their interaction with the ISP, namely:

1) misprinting, which takes place in cases, when the user does not pay the whole attention to the performance of the current action;

2) not reading the readings of the ISP functioning system, which are produced by both experienced and inexperienced users. At the same time, the first ones consider it unnecessary to check the readings of the current state of the ISP, and the second ones-either forget to read the readings, or do not know how to do it;

3) automatic errors occur when the user knows what he should do and how to do it, but does not perform the action normally due to a lack of full attention, due to the apparent simplicity of the action being performed.

In order to reduce the ISP sensibility to systemic mistakes of users three main methods are recommended:

1) blocking of potentially dangerous actions of users until the ISP software confirms its correctness;

2) checking by the ISP software of possible actions of users before its performance;

3) independent selection of the necessary commands or parameters by the ISP software, in which the users are only required to check their correctness.

The most effective seems to be the third method, anyway, its practical implementation is associated with material difficulties.

Another important criterion for the effectiveness of UI is the speed of work. In its pure form, this criterion is rarely evaluated, but it almost always remains one of the determining factors in the overall assessment of the quality of individual 
entrepreneurs. Usually, the best UI is considered to be the one in which less time is spent on completing tasks by users within the ISP.

The main factor that has a significant impact on the subjective satisfaction of users with ISP capabilities is a sense of control over all actions in the process of interacting with it. While there is still a significant part of users for whom the use of ISP software has not become a habitual action. For them, the feeling that they are not able to control the work on ISP is a source of great stress. For more advanced users, the lack of a sense of control leads to dissatisfaction with the ISP capabilities.

The resulting set of indicators for the expert assessment of the quality of UI development in the context of its main qualitative characteristics in relation to ISP is shown in the table.

Table

Indices of the expert evaluation of the quality of development of UI ISP

\begin{tabular}{|c|c|c|c|}
\hline Quality criteria & Qualitative characteristics & Quality indices & $\begin{array}{l}\text { Measuring } \\
\text { units }\end{array}$ \\
\hline 1 & 2 & 3 & 4 \\
\hline \multirow[t]{5}{*}{$\begin{array}{l}\text { 1. Speed of the IU } \\
\text { operation }\end{array}$} & \multirow[t]{2}{*}{ 1.1. Efficiency } & $\begin{array}{l}\text { 1.1.1.Successful performance of } \\
\text { functions from the first attempt }\end{array}$ & $\%$ \\
\hline & & $\begin{array}{l}\text { 1.1.2. Correct function description from } \\
\text { the first attempt }\end{array}$ & $\%$ \\
\hline & \multirow[t]{2}{*}{ 1.2. Performance } & $\begin{array}{l}\text { 1.2.1. Time of the first attempt } \\
\text { performance }\end{array}$ & $\mathrm{c}$ \\
\hline & & 1.2.2. Relative performance & $\%$ \\
\hline & 1.3. Satisfaction & $\begin{array}{l}\text { 1.3.1. Evaluation of the clarity of the } \\
\text { performance of functions }\end{array}$ & grade \\
\hline \multirow[t]{3}{*}{$\begin{array}{l}\text { 2. Number of IU } \\
\text { mistakes }\end{array}$} & 2.1. Efficiency & $\begin{array}{l}\text { 2.1.1. Mistakes, revealed by the ISU } \\
\text { software }\end{array}$ & pes. \\
\hline & 2.2. Performance & $\begin{array}{l}\text { 2.2.1. Average time for the correction } \\
\text { of mistakes }\end{array}$ & $\mathrm{s}$ \\
\hline & 2.3. Satisfaction & $\begin{array}{l}\text { 2.3.1. Evaluation of the information } \\
\text { about mistakes }\end{array}$ & grade \\
\hline \multirow{5}{*}{$\begin{array}{l}\text { 3. Speed of the IU } \\
\text { learning }\end{array}$} & \multirow[t]{3}{*}{ 3.1. Efficiency } & 3.1.1. Number of functions in a ISU & pes. \\
\hline & & $\begin{array}{l}\text { 3.1.2. Per cent of users, who have } \\
\text { mastered all functions }\end{array}$ & $\%$ \\
\hline & & $\begin{array}{l}\text { 3.1.3. Per cent of successfully } \\
\text { performed functions }\end{array}$ & $\%$ \\
\hline & 3.2. Performance & $\begin{array}{l}\text { 3.2.1. Average time to learn a function } \\
\text { to successfully solve a problem }\end{array}$ & $\mathrm{c}$ \\
\hline & 3.3. Удовлетворенность & $\begin{array}{l}\text { 3.3.1. Average evaluation of the quality } \\
\text { of the learning of the ISU operation }\end{array}$ & grade \\
\hline \multirow{3}{*}{$\begin{array}{l}\text { 4. Subjective } \\
\text { satisfaction of the } \\
\text { IU }\end{array}$} & 4.1. Efficiency & $\begin{array}{l}\text { 4.1.1. Number of addresses to the } \\
\text { support division }\end{array}$ & pes. \\
\hline & 4.2. Performance & $\begin{array}{l}\text { 4.2.1. Effective time for the one task } \\
\text { performance }\end{array}$ & $\min$. \\
\hline & 4.3. Satisfaction & 4.3.1. Evaluation of the support service & grade \\
\hline
\end{tabular}




\section{Conclusion.}

The offered system of basic quality characteristics and their corresponding quality indicators does not pretend to be fully accounting for absolutely all the quality characteristics of UI ISP. It is open and can easily be supplemented with new quality criteria, their qualitative characteristics and evaluation indicators in relation to the use of UI ISP in the process of managing the production and economic activities of the enterprise.

\section{References}

1. Astafieva V.V. Principles and Rules of the User Interface Design / V.V. Astafieva. - Text: direct // Molodoy Uchenyi. - 2020. - № 1 (291). - P. 10-14. URL: https://moluch.ru/archive/291/66058/ (date of address: 05.06.2021).

2. GOST R ISO 14915-1-2010. Ergonomics of Multimedia User Interfaces. Part 1. Design Principles and Structure.

3. ГОСТ Р ИСО 9241-151-2014. Ergonomics of the Human-System Interaction. Part 151. Guide for the Design of Internet User Interfaces.

4. Cooper A., Reimann R., Cronin D., Nossel C. Interface. Elements of the Interaction Design. 4 ed. - Peter, 2017. - 720 p.

5. Larin S.N., Zhilyakova E.V. Methods, Composition of Indices and the Algorithm of the Performance of the Expert Evaluation of the Innovative Software Quality // Innovatsionnaya Nauka, 2015. №4-1. P.73-76.

6. Mandel T. User Interface Development. - M.: DMK Press, 2008. - 420 p.

7. Mednikova O.V. Design of Interfaces: Guidance Manual. - M.: RUT (MIIT), 2019. - 68 p.

8. Miyalovich Z., Milichev D. Technologies of the Development of User Interfaces // Otkrytye Systemy. SUBD, 2013. № 10 [Electronic resource]. URL: https://www.osp.ru/os/2013/10/13039072 (date of address: 05.06.2021).

9. Nesterov A.V. Elements of Expert \& Research Activities. - M.: HSE Publishing House, 2009. - 163p.

10. Sayapin O.V., Bystrakova I.A., Tikhanychev O.V., Chiskidov C.V. Development of Interfaces of Applied Programs: Modeling or Prototyping // Applied Information Science, 2020. №1 (85).

11. Spitsina I.A. Application of the Systemic Analysis at the Development of the User Interface of Information Systems: Manual. - Ekaterinburg: Edition of the Ural University, 2018. - 100 p. 
12. Tidwell J. Desing of User Interfaces. $-\mathrm{SPb} .:$ Peter, 2008. $-416 \mathrm{p}$.

13. ISO 25000:2005 TO. - Guide for the Application of New Series of Software Quality Standards on the Basis of Communitization of ISO 9126:1-4: 2002 and ISO 14598: 1-6:1998-2000.

14. International Standard ISO 9241: Ergonomic requirements for office work with visual display terminals (VDTs) - Part 11. Guidance on usability. First edition. 1998. $-28 \mathrm{p}$.

15. International Standard ISO/IEC 9126: Information Technology - Software Product Quality, 1999. - 308 c.

16. Alepis E., Virvou M. Object-Oriented User Interfaces for Personalized Mobile Learning. - Springer, 2014. - 135 p.

17. Lewis J.R. Practical Speech User Interface Design. CRC Press, 2010.336 p.

18. Steimle J. Pen-and-Paper User Interfaces. Integrating Printed and Digital Documents. - Springer, 2012. - 202 p. 